TEME, г. XLV, бр. 1, јануар - март 2021, стр. 299-314

Прегледни рад https://doi.org/10.22190/TEME190415016M

Примљено: 15. 4. 2019.

Ревидирана верзија: 13. 6. 2020.

Одобрено за штампу: 26. 2. 2021.

\title{
IDENTIFICATION AND ASSESSMENT OF CURRENCY CRISES IN THE REPUBLIC OF SERBIA
}

\author{
Milan Marković ${ }^{1 *}$, Ivana Marjanović ${ }^{2}$ \\ ${ }^{1}$ University of Niš, Innovation Center, Niš, Serbia \\ ${ }^{2}$ University of Niš, Faculty of Economics, Niš, Serbia
}

\begin{abstract}
The aim of the paper is to identify the episodes of currency crises in the Republic of Serbia using the exchange market pressure (EMP) index. The country's resilience to currency crises prevents the collapse of the currency and the transfer of negative effects to the entire financial and real sector, so the research and assessment of the factors of currency crises is extremely important. The survey shows that the strongest strikes on the Serbian dinar were in the period of the global financial crisis in 2008, so that adjusting to shocks from abroad is crucial for the sustainability of the applied managed floating exchange rate regime. On the other hand, the stability of the national currency depends mainly on the achieved macroeconomic results, which are presented globally using the misery index.
\end{abstract}

Key words: currency crisis, floating exchange rate, foreign exchange reserves, exchange market pressure (EMP) index, misery index.

\section{ИДЕНТИФИКОВАЊЕ И ОЦЕНА ВАЛУТНИХ КРИЗА У РЕПУБЛИЦИ СРБИЈИ}

Апстракт

Циљ рада јесте уочавање епизода валутних криза у Републици Србији коришћењем индекса притиска на девизно тржиште (ИПДТ). Отпорност земље валутним кризама онемогућава слом валуте и пренос негативних ефеката на целокупни финансијски и реални сектор, тако да су истраживање и оцена фактора валутних криза од изузетне важности. Рад показује да су најјачи удари на динар у Србији били у периоду настанка светске финансијске кризе из 2008. године, тако да је прилагођавање шоковима из иностранства од пресудног значаја за одрживост примењеног режима руковођеног флуктуирајућег девизног курса. Сa друге стране, стабилност националне валуте зависи углавном од постигнутих

\footnotetext{
* Аутор за кореспонденцију: Милан Марковић, Универзитет у Нишу, Иновациони центар, Универзитетски трг 2, 18000 Ниш, Србија, markovicmilan89@gmail.com
} 
макроекономских резултата, који се у глобалу приказују помоћу индекса мизерности.

Кључне речи: валутна криза, флуктуирајући девизни курс, девизне резерве, индекс притиска на девизно тржиште (ИПДТ), индекс мизерности.

\section{INTRODUCTION}

Each country faces the problem of selecting an adequate exchange rate regime. The optimal solution is made depending on the existing structural characteristics of the specific economy. There is a general rule that small open economies facing internal problems choose a fixed exchange rate. However, in many basic models of currency crises, monetary authorities enforce unsustainable macroeconomic policies that lead to the fixed exchange rate regime to be abandoned over time (Obstfeld, 1994).

Although a fixed exchange rate may be a stabilizing factor bearing in mind the visible monetary stability, its inflexibility leads to a deviation from the real exchange rate. In fact, the fixedness of the exchange rate spends the central bank's foreign currency reserves due to, for example, the balance of payments deficit. However, the floating exchange rate also shows some anomalies from the point of view of this research. It is true that in this exchange rate regime, the possibility of domestic currency being overstated is diminished. But there is also a great opportunity for the pursuit of speculative transactions while the domestic economy is under considerable influence of changes in the world market. Namely, capital liberalization undoubtedly contributed to both the fixed and floating exchange rate regime being equal to the target of speculators, as well as all possible modalities of foreign exchange rates in general.

The possibility of a currency crisis arises whenever the exchange rate is rising rapidly (direct notation - the depreciation of the national currency). This means that in the floating exchange rate regime, it is possible to expect a currency collapse. This is true for countries with low production and geographical diversification of exports (the case of Serbia), as well as for those with a huge budget deficit and external debt relative to gross domestic product. Under the conditions of developed international economic and financial relations, the currency crisis is spreading rapidly. The paper will show the possibility of currency crises in the floating exchange rate regime, the basic internal and external determinants of the outbreak of currency crises in the Republic of Serbia, as well as assess the exposure of the Serbian economy to currency disturbances based on the exchange market pressure (EMP) index and other indicators. The goal is to discover the causes of previous currency crises in order to act in a timely and adequate manner in the future. 


\section{THEORETICAL FRAMEWORK OF CURRENCY CRISES}

The expansionary monetary and fiscal policy, according to the models of the first generation of currency crises (deterministic theory of currency crises), results in a constant and often irrecoverable loss of foreign currency reserves by the monetary authority (Ćirović, 2000). Krugman defines the first generation of currency crises related to the fixed exchange rate regime in the following way:

"The old models of currency crises are based precisely on the thesis that countries have an uncontrolled need to monetize their budget deficits and thus face the crisis in order to defend the fixed exchange rate." (Krugman, 1996, p. 345)

According to models of the second generation of currency crises, emphasis is put on the expectations of market players as to whether there will be an excessive expansion of the loan and whether the currency crisis will be transferred from other countries (Ćirović, 2000). It is also important to assess the ability of the central bank to defend the exchange rate. In this sense, the crises are self-fulfilling and can arise in all economies where there is an expectation that depreciation of the national currency will occur in the future period.

Expansionary economic policy is not sustainable in the long run in countries with balance of payments problems. Monetary problems of the country often denote the impossibility of achieving currency stability. The inadequate foreign exchange policy of national central banks can significantly contribute not only to the currency, but also to the economic crisis. Therefore, the International Monetary Fund monitors and controls the monetary situation of many countries in the world, primarily monetary movements in developing countries. Structural reforms, consolidation of public finances and the maintenance of monetary stability are proposed.

In the conditions of globalization of financial markets and the liberalization of capital movements, the space for the movement of speculative capital is expanding. Currency crises from one market are transferred to financial markets in other countries. Taking into account the factors of one of the biggest currency crises in history, Bustelo emphasizes the following:

"One of the main messages of the East Asian financial crisis is that ruthless and insufficiently measured financial liberalization drastically increases the sensitivity to speculative attacks" (Bustelo, 1998, p. 22).

Foreign short-term capital often attacks currencies that are already slightly underestimated, anticipating that this underestimation is higher. The main goal is to make a profit - to buy foreign currency cheap (so-called long position), and sell them at a higher price (the so-called short position). 
The Republic of Serbia has an underdeveloped and shallow foreign exchange market, so it is faced with a much greater possibility of exchange rate fluctuations. Capital inflows are a necessary condition to cover the current account deficit, but if most of that capital is speculative capital, it can lead to economic and financial collapse. On the other hand, the inflow of long-term capital (foreign direct investment, long-term loans) is significantly less dangerous for monetary stability due to its long-term nature.

The weak financial sector, the balance of payments deficit (primarily the trade deficit, above all) and the high public debt ratio represent unfavorable characteristics of the economy, which in this case cannot be immune to the spread of currency crises. Therefore, the increase in exports, as the best source of foreign exchange, is a key solution for reducing the deficit, but also for long-term financial stability (Marković, \& Marković, 2015).

Currency crises are most often associated with the regime of fixed exchange rates. However, this does not mean that countries with a variable exchange rate are immune to the impact of speculative capital. Such countries do not have the obligation to defend the established parity, but occasionally intervene to ensure the stability of the exchange rate, as the most important price in the national economy. Here, the central bank is not obliged to maintain a constant value of the national currency because stability does not mean the invariable exchange rate. In the Republic of Serbia, the central bank has no obligation to defend the exchange rate, but it often intervenes to prevent excessive daily oscillations. The instability of the foreign exchange rate, as Miljković points out, is the main factor of speculative attacks in this exchange rate regime and states the following:

"The space for speculative attacks in the floating exchange rate regime opens with seasonal and cyclical oscillations of exchange rates, which are the result of seasonal and cyclical fluctuations in income and payments based on economic transactions of a foreign country." (Miljković, 2007, p. 342)

The following chart shows the destabilizing effect of attacks on speculative capital in the country with the adopted floating exchange rate regime.

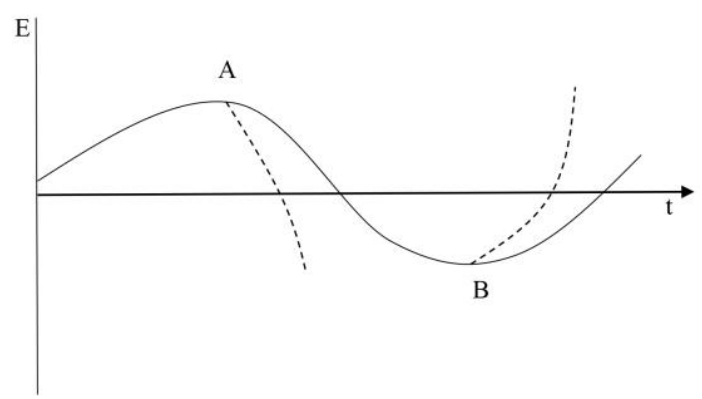

Graph 1. Destabilizing effect of speculative capital in the floating exchange rate regime Source: Miljković, 2007, p. 343. 
During the period when the country has greater liabilities than claims from abroad, the foreign exchange market experiences a higher demand for foreign currency and the weakening of the national currency value. Thus, the national currency is in the phase of depreciation because companies increase the demand for foreign currency in order to settle their obligations abroad. Speculators in point A sell foreign currency (at a higher exchange rate - E). That is the point, i.e. the moment for the attack of speculative capital. They expect the appreciation of the national currency due to seasonal opportunities. Due to these speculative activities, the exchange rate significantly drops than would have been in the case of normal, usual seasonal changes. Therefore, the curve becomes significantly steeper (dashed line) in relation to the (full) curve representing normal seasonal shocks.

Conversely, if they predict depreciation of the national currency, speculators increase the demand for foreign currency (point B). That is why the exchange rate goes quite high. In particular, the negative situation is that when the effect of recognition and other market participants assume that the exchange rate will increase. When assessing an adequate moment, speculators are now carrying out opposite transactions. They sell foreign currency at a significantly higher price and generate quite a few margins.

The statement is simple: speculative capital causes even higher oscillations of the exchange rate relative to those normal that would happen in the case of seasonal changes. All this analysis tells us that in the floating exchange rate regime there can be a destructive effect of speculative attacks on the foreign exchange market. A floating exchange rate system increases the likelihood of currency crises in countries receiving foreign capital in large amounts and in which there is a risk of a worsening of the macroeconomic position. These are countries that are dependent on foreign capital with which they cover the current account deficit.

Bearing in mind that there is a high degree of euroization in Serbia (Stanišić, \& Janković, 2014), studying the EMP index can be of great importance. In such circumstances, the currency crisis is very easily spread to the entire financial sector. Therefore, the intervention of the National Bank of Serbia in order to prevent speculative attacks, within the policy of the managed floating exchange rate, are very important. They are manifested through the sale and purchase of foreign currency in the foreign exchange market.

\section{METHODOLOGY}

One of the most used tools used in estimating the potential currency crisis is the EMP index. Eichengreen, Rose and Wyplosz (1996) state that the examination of the movement of the EMP index is very important for assessing the country's resistance to financial crises. Also, Tatomir 
(2009) in his study points out that tensions on foreign exchange markets can often create strong currency pressures.

Girton and Roper (1977) are the authors who first used this index. The most common formula for the EMP index is calculated as follows (Kaminsky, Lizondo, \& Reinhart, 1998; Tatomir, 2009; Nikolić, 2009):

$$
E M P_{t}=\frac{\Delta e_{t}}{e_{t-1}}-w \frac{\Delta R_{t}}{R_{t-1}}
$$

where:

$E M P_{t}$ - exchange market pressure index (on a monthly basis),

$\Delta e_{t}$ - monthly change in the nominal exchange rate,

$e_{t-1}$ - the nominal exchange rate of the dinar against the euro in the previous month,

$w$ - the ratio of the standard deviation of the rate of change in the nominal exchange rate of the dinar against the euro and the standard deviation of the rate of change in foreign currency reserves at the monthly level, i.e. $w=\sigma r e_{t} / \sigma r R_{t}$,

$\Delta R_{t}$ - monthly change in the level of foreign exchange reserves,

$R_{t-1}$ - the level of foreign currency reserves in the previous month.

It contains the basic variables on the basis of which the currency crisis is defined, which is the sudden depreciation of the national currency and the sharp fall in the level of foreign exchange reserves. This causes this index to be higher, increasing the chances of speculative attacks.

The currency crisis begins as soon as the value of the EMP index (at the monthly level) exceeds a certain threshold. This value is most often obtained as the sum of 3 standard deviations of the EMP index at the monthly level and the arithmetic mean of this index for the entire period of research (although there are studies that define a lower threshold, e.g. 2 standard deviations).

"The main factor influencing the expectations of investors and speculators is the "unfavorable" news about some economic fundamentals (inflation, budget deficit, currency overestimation, the risk of over-indebtedness, and the like)." (Nikolić, 2009, p. 85)

Therefore, the indicator will be introduced in the analysis - the misery index, which contains the main indicators of macroeconomic efficiency.

The misery index reflects the state of the economy and the success in managing economic policy. In addition, it also shows the economic dimension of the quality of life of the population (Cavanaugh, \& King, 1988), and is often used in the analysis of poverty in some countries. The original version of the index was defined by Okun as a sum of annual inflation rates and unemployment rates, while economist Barro expanded the coverage of this index by introducing the interest rate and growth rate of the real gross domestic product (Ewa, 2009). After some modifications, the final version of 
this index to be used in the research is (Rađenović, \& Kostić, 2015; Kolaneci, Duzha, \& Lika, 2016):

$$
\begin{aligned}
\text { Misery index } & =\text { unemployment rate }+ \text { inflation rate }+ \text { interest rate } \\
& -\% \Delta \text { in real gross domestic product }
\end{aligned}
$$

The reference interest rate was taken for the interest rate. Sources of data were obtained from the database of the National Bank of Serbia. These data include the following indicators: the monthly level of foreign currency reserves expressed in euros, the nominal exchange rate of the dinar against the euro at the end of the month and the reference interest rate also on a monthly basis. Among other indicators aside, the inflation rate and the unemployment rate, both on an annual basis, as well as the valid reference interest rate at the end of the year. Data on the movement of real gross domestic product were obtained on the basis of the data of the Public Finance Bulletin of the Ministry of Finance of the Republic of Serbia. Correlation and regression analysis were used to evaluate the relationship between individual variables and the influence of the same on the EMP index. The survey covers a twelve-year period from October 2006 to September 2018.

Research hypotheses are:

$\mathrm{H}_{1}$ : Currency crises are possible in the fixed exchange rate regime and also in the floating exchange rate regime,

$\mathrm{H}_{2}$ : There is a weak correlation between the rate of change in the exchange rate and the rate of change in foreign reserves, which confirms the determination of the National Bank of Serbia to intervene in the foreign exchange market only to prevent speculative attacks on the daily level,

$\mathrm{H}_{3}$ : External shocks significantly influence the possibility of developing a currency crisis in the Republic of Serbia.

\section{RESULTS AND DISCUSSION}

Based on the survey methodology presented, the EMP index will first be calculated. In analyzing this index for the entire research period, three characteristic sub-periods can be distinguished. The first one covers the period from October 2006 to mid-2009, where the strongest pressures on the national currency are identified. The period until mid-2013 is characterized by few fluctuations in the movement of the EMP index. The most stable sub-period is related to 2014, 2015, 2016, 2017 and 2018.

The most dominant factor for instability in the first sub-period is the impact of the global economic and financial crisis. In October 2008 Serbia, according to this indicator, had strong pressures on the dinar and currency crisis. This also shows the maximum value of the EMP index recorded for this month. Slight pressures were registered in November 2007, November 2008, January 2009 and June 2011 (if the threshold drops from 3 to 2 stand- 
ard deviations, they also represent periods with a currency crisis). In all these "crisis" months, the main trigger is the depreciation of the Serbian dinar. During the second sub-period, the most important determinants are internal shocks, an unstable monetary situation and a budget deficit. The period since 2014 is characterized by the extremely low values of the EMP index, without any possible currency crises. Although in theory they mostly relate to the fixed exchange rate, based on the preliminary consideration and the results of this empirical research, the hypothesis according to which currency crises are also expressed in the (managed) floating exchange rate regime is confirmed.

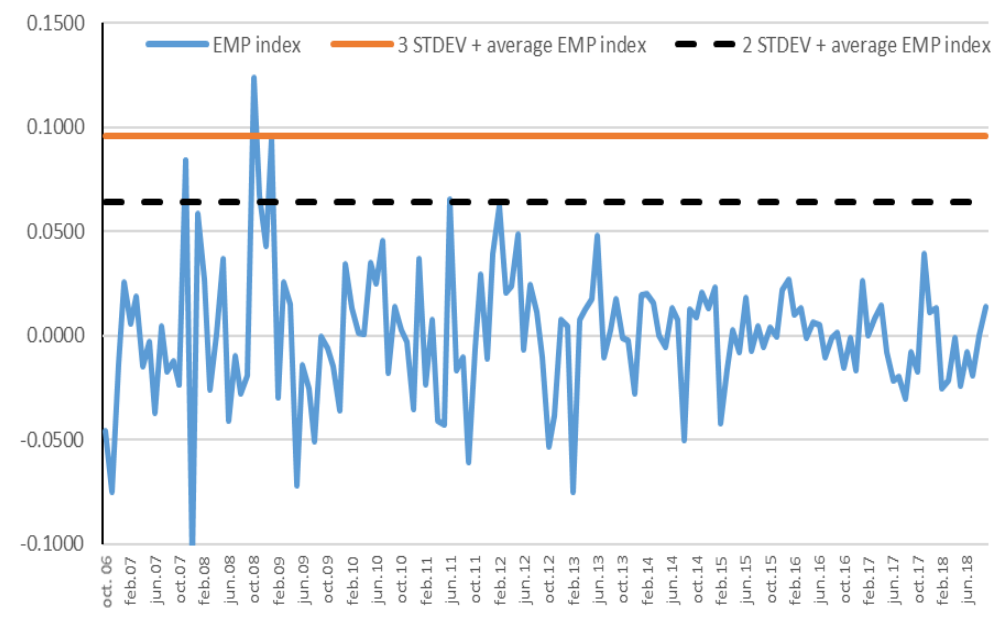

Graph 2. Movement of the EMP index in the Republic of Serbia for the period from October 2006 to September 2018

Source: Calculation and presentation of the authors based on data from the National Bank of Serbia, 2018.

Several studies have examined the main determinants of the EMP index (Patnaik, \& Pundit, 2019; Aizenman, \& Hutchison, 2012; Aizenman, Lee, \& Sushko, 2012; Aizenman, \& Binici, 2016; Feridun, 2009; Patnaik, Felman, \& Shah, 2017), whereby the level of GDP, current account balance as a percentage of GDP (CAB), public debt as a percentage of GDP (PD), foreign exchange reserves as a percentage of GDP (FERGDP) and inflation (INF) were revealed to be the most prominent. Therefore, the influence of these variables on the EMP index in the Republic of Serbia is examined. The following regression model is formed:

$$
E M P_{t}=\beta_{0}+\beta_{1} G D P_{t}+\beta_{2} C A B_{t}+\beta_{3} P D_{t}+\beta_{4} F E R G D P_{t}+\beta_{5} I N F_{t}+\varepsilon_{t}
$$

The results of the augmented Dickey-Fuller test indicate that the variables in the regression analysis are non-stationary at level, but stationary at first differences. Therefore, it is necessary to test for cointegration. The Johansen's test indicates that there are no cointegrating equations, therefore, 
the model with the first differences is evaluated. To examine the validity of the model, autocorrelation, multicollinearity and heteroscedasticity are tested. Since the model suffers from heteroscedasticity the regression model is assessed using the Newey-West estimation procedure and the results are presented in Table 1.

Table 1. Results of the estimated regression model

\begin{tabular}{|c|c|c|c|c|c|c|}
\hline & \multirow[t]{2}{*}{ Coef. } & \multirow{2}{*}{$\begin{array}{l}\text { Newey-West } \\
\text { Std. Error }\end{array}$} & \multirow[t]{2}{*}{$\mathrm{t}$} & \multirow[t]{2}{*}{ Sig. } & \multicolumn{2}{|c|}{ 95\% Confidence Interval } \\
\hline & & & & & Lower Bound & Upper Bound \\
\hline GDP & .00000045 & .00000013 & 3.47 & .001 & .00000019 & .00000071 \\
\hline CAB & 46.25627 & 16.72461 & 2.77 & .006 & 13.17791 & 79.33463 \\
\hline PD & 6.126626 & 4.74529 & 1.29 & 199 & -3.258731 & 15.51198 \\
\hline FERGDP & -0.260691 & .0344339 & -7.57 & .000 & -.3287952 & -.1925866 \\
\hline INF & -.000291 & .0016437 & -.18 & .860 & -.0035417 & .0029602 \\
\hline constant & -.000835 & .0026436 & -.32 & .753 & -.0060633 & .004394 \\
\hline
\end{tabular}

The obtained results show that changes in the level of GDP, current account balance and foreign exchange reserves represent significant determinants of the EMP index in the Republic of Serbia, while inflation and public debt do not have significant influence. As for the impact of perceived relationships, it can be noticed that the changes in the level of GDP and current account balance have a positive influence on the EMP index, while the foreign exchange reserves (as a percentage of GDP) have a negative influence on the value of the EMP index. The estimated model is statistically significant at the significance level of $1 \%(F(5,134)=28.93$, Prob > $\mathrm{F}=0.0000$ ), with the adjusted $\mathrm{R}$ squared of $37.17 \%$. Therefore, in predicting the EMP index, it is also important to consider changes in the GDP, current account balance and particularly, foreign exchange reserves.

Along with the assessment of the movement of the EMP index, it is necessary to observe the movement of the exchange rate. Analyzing the nominal exchange rate movements with a monthly level, it becomes clear that there has been a high level of stability since mid-2013. In the period from 2007 to 2012, the dinar depreciated against the euro by $43.95 \%$, while for the next six-year period it lost value by only $6.02 \%$.

Changes in the level of foreign exchange reserves are recorded in the following graph. Compared to October 2006, the level of foreign exchange reserves increased and at the end of the research period amounted to EUR 12,302 million, an increase of $44.28 \%$. However, although the correlation coefficient between the rate of change in foreign exchange reserves and the exchange rate is negative, there is a very weak link, because it is only -0.20 . This leads to the conclusion that foreign exchange reserves are used only to suppress excessive fluctuations in the exchange rate on a daily basis, which is the goal of the policy of the managed floating exchange rate. Therefore, the policy of the National Bank of Serbia was conducted in order to preserve the 
stability of the exchange rate, and not its invariability, so that the second hypothesis of the research was confirmed.

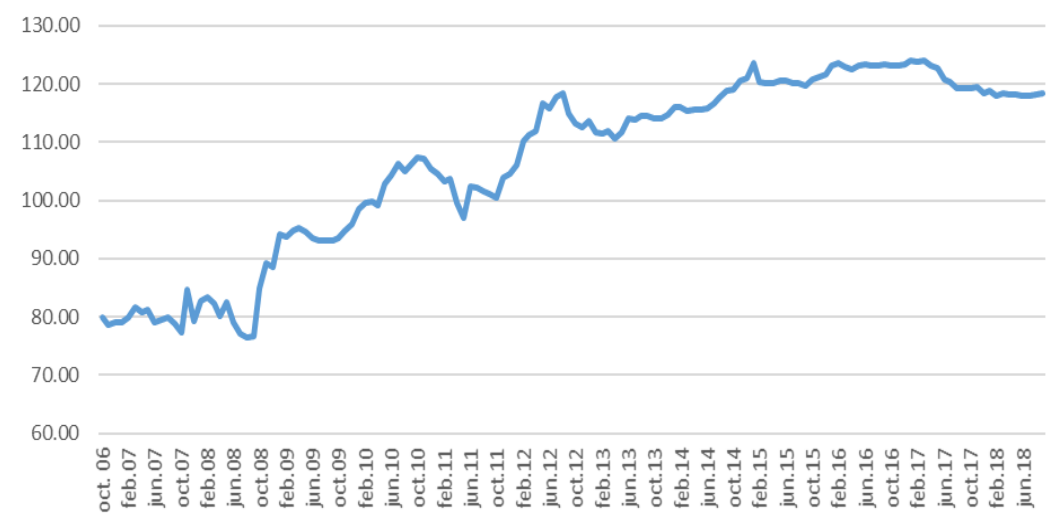

Graph 3. Movement of the monthly exchange rate of the dinar against the euro in Serbia in the period from October 2006 to September 2018 (end of the period)

Source: Authors' presentation based on data from the National Bank of Serbia, 2018.

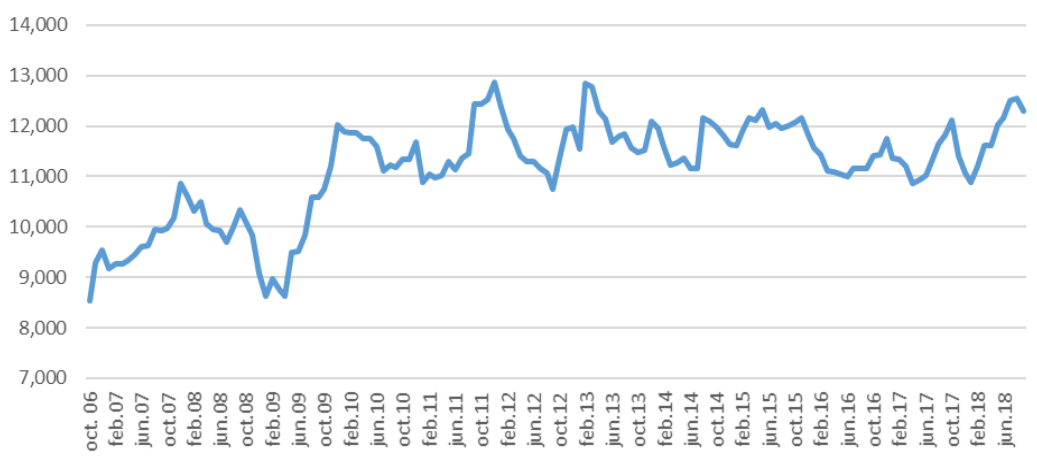

Graph 4. Changes in the level of foreign exchange reserves in Serbia in the period from October 2006 to September 2018 (in millions of EUR)

Source: Authors' presentation based on data from the National Bank of Serbia, 2018.

The reference interest rate (Graph 5), used by the National Bank of Serbia as a money supply regulator, was not directly related to changes in the foreign exchange market and the removal of existing pressures. This means that this instrument was not used (in addition to foreign exchange reserves) in order to stabilize the foreign exchange rate. This fully corresponds to the aforementioned euroization of the Serbian economy, which leads to the conclusion that monetary policy becomes inefficient in that case. On the other hand, it is clear that the exchange rate channel is dominant. The correlation coefficient between the rate of change in the nominal exchange rate of 
the Serbian dinar against the euro and the reference interest rate at the monthly level for the stated research period amounted to only -0.10 .

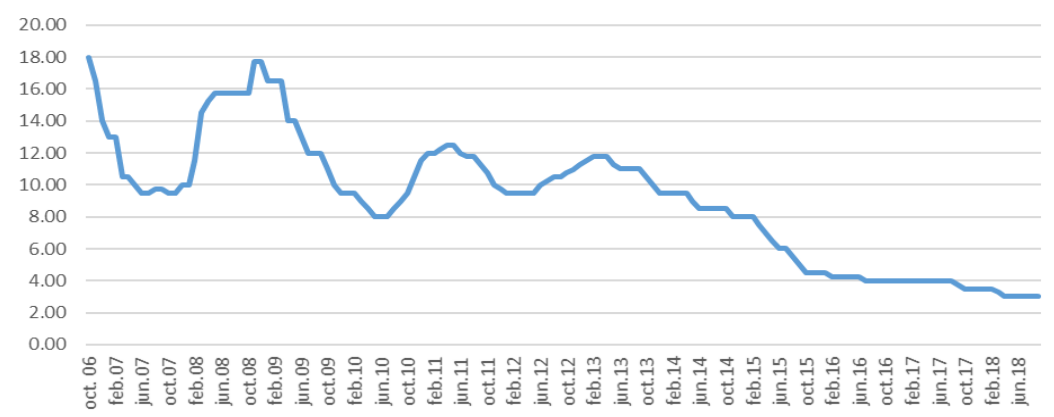

Graph 5. Movement of reference interest rates on a monthly basis in Serbia for the period from October 2006 to September 2018 Source: Authors' presentation based on data from the National Bank of Serbia, 2018.

In more detail, in order to assess the relationship between the exchange rate (ER) and foreign exchange reserves (FER), as well as the relationship between the reference interest rate (RIR) and the exchange rate, a correlation analysis was used (Table 2). The results show that there is a weak inverse relationship between exchange rates and foreign exchange reserves, while the ratio between reference interest rates and foreign exchange rates, although inverse, is not statistically significant. The established relationship means that only $4.16 \%$ of the variance is common, therefore, exchange rates can explain $4.16 \%$ of the variance of foreign exchange reserves variance and vice versa.

Table 2. Correlation between exchange rate, foreign exchange reserves and reference interest rate

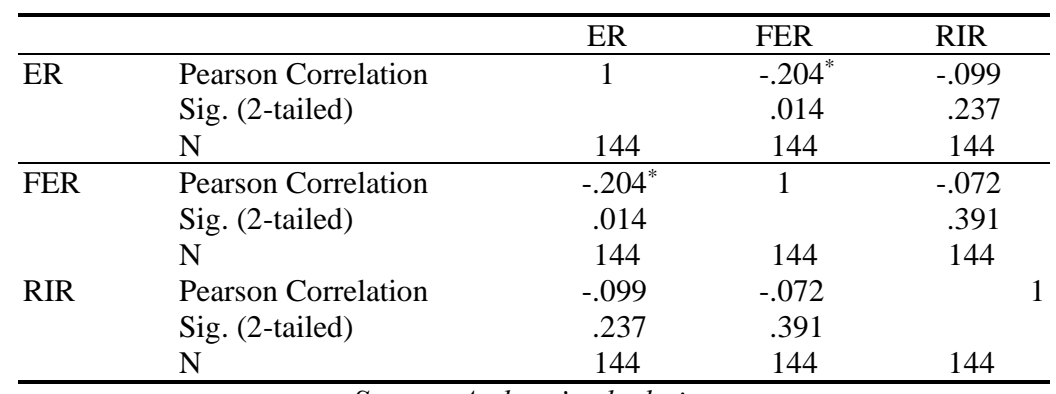

Source: Authors' calculation

Unlike the EMP index that reflects the success in monetary policy management, the misery index shows the "state of health of the economy" and reflects the efficiency of the country's overall economic policy. The fol- 
lowing table (Table 3) computes the values of this index for the entire analysis period. Starting from 2012, when the highest index was registered, there is a continuous decrease trend, which reflects the improvement of the economic situation from year to year. This is the result of well-conducted, primarily fiscal policy, monetary policy, and structural reforms implemented, which is reflected in the reduction of unemployment. In order to lower this index to below $10 \%$, it will be necessary to increase production, which in turn will affect further reduction of the unemployment rate. Since the misery index reflects the internal problems of the economy, it can be concluded that external shocks significantly influence the possibility of a currency crisis, which is in line with the third hypothesis of the research. In 2010 and 2012, the values of this indicator were the highest, but the value of the EMP index was lower and did not exceed the previously defined limit values, as was the case in 2007 and 2008, when there were strong external pressures. The inflation rate was the leading factor in the high misery index, which only affected the depreciation of the national currency, $10.02 \%$ in 2010 and 8.67\%, in 2012.

Table 3. Misery index of the Republic of Serbia in the period from 2007 to 2018

\begin{tabular}{ccrccc}
\hline Year & $\begin{array}{c}\text { Unemployment } \\
\text { rate }\end{array}$ & $\begin{array}{c}\text { Interest } \\
\text { rate }\end{array}$ & $\begin{array}{c}\text { Inflation } \\
\text { rate }\end{array}$ & $\begin{array}{c}\text { The rate of } \\
\text { change in real } \\
\text { GDP }\end{array}$ & $\begin{array}{c}\text { Misery } \\
\text { index }\end{array}$ \\
\hline 2007 & 18,1 & 10,00 & 11,0 & 5,9 & 33,20 \\
2008 & 13,6 & 17,75 & 8,6 & 5,4 & 34,55 \\
2009 & 16,1 & 9,50 & 6,6 & $-3,1$ & 35,30 \\
2010 & 19,2 & 11,50 & 10,3 & 0,6 & 40,40 \\
2011 & 23,0 & 9,75 & 7,0 & 1,4 & 38,35 \\
2012 & 23,9 & 11,25 & 12,2 & $-1,0$ & 48,35 \\
2013 & 22,1 & 9,50 & 2,2 & 2,6 & 31,20 \\
2014 & 19,2 & 8,00 & 1,7 & $-1,8$ & 30,70 \\
2015 & 17,7 & 4,50 & 1,5 & 0,7 & 23,00 \\
2016 & 15,3 & 4,00 & 1,6 & 2,8 & 18,10 \\
2017 & 13,5 & 3,50 & 3,0 & 1,9 & 18,10 \\
2018 & $11,9^{*}$ & $3,00^{*}$ & $2,1^{*}$ & $4,2^{* *}$ & 12,80 \\
\hline
\end{tabular}

Source: Calculation and presentation of authors based on data

from the National Bank of Serbia, 2018, and the Ministry of Finance, 2018.

Note: the latest available data $\left(^{*}\right)$ and projection $\left(^{* *}\right)$ according to the same sources

\section{CONCLUSION}

Currency crises affect almost all countries. That is why monetary authority must act preventively. In this regard, the emphasis is on control of short-term placements from abroad, as well as the increase of required reserves for these assets. Simultaneous internal and external equilibrium is the key objective of the country not to receive a currency crisis. Currency 
crises are often the result of expansively guided fiscal and monetary policy, so measures are required in order to reduce aggregate demand.

A speculative attack is not a necessary condition for the manifestation of the currency crisis. But, based on empirical research, it is an unavoidable factor in the creation or stimulation of the development of currency crises. Developing countries and countries with monetary problems are the ideal ground for the arrival of foreign speculative capital that destroys the monetary system of these countries and prevents the sustainability of currency stability. According to many, the inflow of speculative capital is an additional factor that further deepens the currency crisis. The central bank is the main institution responsible for defending the economy from speculative attacks. The central bank must defeat speculators with its wise policy. The precondition for this is that the central bank has a large volume of foreign exchange reserves.

The survey showed that most of the values of the EMP index were recorded in the period when the global financial crisis came to Serbia (from October 2008 to January 2009), so that the main factor in the eventual currency crisis is disturbances from abroad. They significantly affect the depreciation of the dinar (in the period from 2007 to 2012, the dinar depreciated against the euro by almost $44 \%$ ), and foreign exchange reserves and the change in the reference interest rate were not significantly used in this context bearing in mind the correlation coefficient at the monthly level.

In addition to fiscal adjustment programs, many requirements of international financial institutions, in the event of currency crises, involve the introduction of a currency board. However, this option brings with it many challenges although it largely stabilizes the exchange rate. It is a particularly negative circumstance when such exchange rates are defended over high real interest rates. In this case, a favorable climate for the arrival of short-term speculative capital is created. After the high rates of inflation until 2012, discussions were held in Serbia on the introduction of a crawling band or even a fixed exchange rate regime. However, starting from 2013, inflation has been at the level of the European average, and the overall internal macroeconomic balance has also been achieved. During this period, the Serbian dinar weakened against the euro by only $6 \%$.

Acknowledgment: The paper is a part of the research financed by the Ministry of Education, Science and Technological Development of the Republic of Serbia (Agreements No. 451-03-9/2021-14/200371 and No. 451-03-9/2021-14/200100). 


\section{REFERENCES}

Aizenman, J., \& Binici, M. (2016). Exchange market pressure in OECD and emerging economies: Domestic vs. external factors and capital flows in the old and new normal. Journal of International Money and Finance, 66, 65-87. https://doi.org/$10.3386 / \mathrm{w} 21662$

Aizenman, J., \& Hutchison, M. M. (2012). International Financial Markets and Transmission of the Crisis: Determinants of Exchange Market Pressure and Absorption by International Reserves. Global Economic Crisis. https://doi:10.4337/9781781006306.00012

Aizenman, J., Lee, J., \& Sushko, V. (2012). From the great moderation to the global crisis: exchange market pressure in the 2000s. Open Economies Review, 23(4), 597-621. https://doi.org/10.3386/w16447

Bustelo, P. (1998). The East Asian Financial Crises: An Analytical Survey. ICEI Working Papers, 10.

Cavanaugh, K. L., \& King, K. D. (1988). Simultaneous transfer function analysis of Okun's misery index: Improvements in the economic quality of life through Maharishi's Vedic Science and technology of consciousness. In: Proceedings of the American Statistical Association, Business and Economics Statistics Section (3207-3222). New Orleans, Louisiana: American Statistical Association.

Girton, L., \& Roper, D. (1977). A monetary model of exchange market pressure applied to the postwar Canadian experience. The American Economic Review, 537-548.

Eichengreen, B., Rose, A. K., \& Wyplosz, C. (1996). Contagious currency crises. NBER Working Paper, 5681. DOI: 10.3386/w5681

Ewa, L. (2009). Okun's and Barro's Misery Index as an alternative poverty assessment tool. Recent estimations for European countries. MPRA Paper, 37493.

Feridun, M. (2009). Determinants of exchange market pressure in Turkey: An econometric investigation. Emerging Markets Finance and Trade, 45(2), 65-81. https://doi.org/ 10.2753/ree1540-496x450204

Kaminsky, G., Lizondo, S., \& Reinhart, C. M. (1998). Leading indicators of currency crises. IMF Staff Papers, 45(1), 1-48.

Kolaneci, F., Duzha, J., \& Lika, E. (2016). Estimating Barro misery index in democratic states with application in Albania: 2005-2014. European Journal of Interdisciplinary Studies, 4(2), 142-160.

Krugman, P. (1996). National Bureau of Economic Research Macroeconomics Annual 1996. In: Ben S. Bernanke \& Julio J. Rotemberg (Eds.): Are Currency Crises SelfFulfilling? (345-407). Massachusetts: MIT Press.

Marković, M., \& Marković, I. (2015). Increasing exports - the condition for achieving external and internal macroeconomic balance of the Republic of Serbia. TEME, 39(4), 1183-1198.

Miljković, D. (2007). Međunarodne finansije [International finances], Beograd: Ekonomski fakultet.

Ministarstvo finansija. Bilten javnih finansija [Public Finance Bulletin]. Br. 167 (2018). Retrieved from http://www.mfin.gov.rs/UserFiles/File/bilten\%20javne \%20finansije/2018/167\%20Bilten\%20javnih\%20finansija.pdf

Narodna banka Srbije. Statistika [Statistics]. (2018). Retrieved from https://www.nbs. rs/internet/cirilica/80/index.html

Nikolić, I. (2009). First signals of currency crisis in Serbia. Industrija, 37(1), 75-86.

Obstfeld, M. (1994). The Logic of Currency Crises. NBER Working Paper Series, 4640.

Patnaik, I., Felman, J., \& Shah, A. (2017). An exchange market pressure measure for cross country analysis. Journal of International Money and Finance, 73, 62-77. https://doi.org/10.1016/j.jimonfin.2017.02.004 
Patnaik, I., \& Pundit, M. (2019). Financial Shocks and Exchange Market Pressure. SSRN Electronic Journal. https://dx.doi.org/10.2139/ssrn.3590161

Rađenović, Ž., \& Kostić, Z. (2015). Quantitative analysis of potential currency crisis in the Republic of Serbia. Škola biznisa, 12(2), 21-31. https://doi.org/10.5937/skolbiz29698

Stanišić, N., \& Janković, N. (2014). Strah od fluktuiranja kursa dinara i nezvanična evroizacija u Srbiji [Fear of fluctuating the exchange rate of the dinar and unofficial euroization in Serbia]. In: Jovanović-Gavrilović, B. \& Žarković-Rakić, J. (Eds.): REFORME I RAZVOJ - Stanje, rezultati i početak pregovora Srbije sa EU (103-115). Beograd: Naučno društvo ekonomista Srbije sa Akademijom ekonomskih nauka i Ekonomski fakultet u Beogradu.

Tatomir, S. (2009). Exchange market pressure on the Croatian Kuna. Financial theory and practice, 33(2), 187-199.

Ćirović, M. (2000). Devizni kursevi [Exchange rates]. Beograd: Bridge company.

\section{ИДЕНТИФИКОВАЊЕ И ОЦЕНА ВАЛУТНИХ КРИЗА У РЕПУБЛИЦИ СРБИЈИ}

Милан Марковић ${ }^{1}$, Ивана Марјановић $^{2}$

${ }^{1}$ Универзитет у Нишу, Иновациони центар, Ниш, Република Србија

${ }^{2}$ Универзитет у Нишу, Економски факултет, Ниш, Република Србија

\section{Резиме}

Сагледавајући различите генерације валутних криза, валутне кризе представљају резултат погрешно вођене макроекономске политике, као и спољних шокова који се огледају кроз шпекулативне нападе на валуту, односно монетарни систем земље. Истраживање показује да су валутне кризе могуће подједнако и у режиму фиксног и у режиму флуктуирајућег девизног курса. Република Србија се определила за управљано флуктуирајући девизни курс, тако да је задатак Народне банке Србије да одржи стабилан девизни курс у циљу избегавања шпекулативних напада на валуту, али не да утиче директно на његов ниво, који се формира на основу кретања понуде и тражње на девизном тржишту. О томе говоре резултати корелационе анализе, тј. да је кретање девизних резерви слабо повезано са порастом номиналног девизног курса у Републици Србији (изузев код периода са валутном кризом).

Индекс притиска на девизном тржишту јесте најкоришћенији алат за процену настанка валутне кризе. Према овом индексу од октобра 2006. године, па до септембра 2018. године, октобар 2008. године био је најкритичнији са становишта валутне стабилности услед наглог слабљења динара. Основни фактор који је доминирао у овом периоду (крај 2008. и почетак 2009. године) јесу шокови из иностранства, услед преноса ефеката светске економске и финансијске кризе. Како је канал девизног курса у Републици Србији јако активан услед високог степена незваничне евроизације, веома је битна стабилизација девизног курса која се манифестовала у другој половини анализираног периода, што је резултат одговорно вођене фискалне, монетарне и девизне политике. О томе сведочи и индекс мизерности, који је од 2013. године у континуираном паду. Он је, између осталог, показатељ ефикасности економске политике једне земље. Међутим, истраживање је показало да стање у домаћој економији није од пресудног значаја за могућност јављања валутне кризе, јер су у 2010. и 2012. години остварене највише вредности индекса мизерности, а то се (и по- 
ред високе депресијације српског динара у овим годинама) није одразило на прелазак индекса притиска на девизно тржиште изнад претходно дефинисаног прага. Ипак, консолидација јавних финансија може побољшати очекивања тржишних субјеката и онемогућити велике осцилације у кретању капитала. 